\begin{tabular}{|c|c|c|}
\hline & International Journal of Current Research in & \\
\hline & Biosciences and Plant Biology & \\
\hline $\begin{array}{l}\text { EXEE } \\
\text { PUBL }\end{array}$ & $\begin{array}{c}\text { ISSN: 2349-8080 (Online) • Volume } 3 \bullet \text { Number } 5 \text { (Ma } \\
\text { Journal homepage: www.ijcrbp.com }\end{array}$ & \\
\hline
\end{tabular}

\title{
Investigations into Taro [Colocasia esculenta (L.) Schott] Leaf Blight Outbreak and Identification of Resistant Cultivars in Akwa Ibom State, Nigeria
}

\author{
E. E. Bassey ${ }^{*}$, G. S. Umoh ${ }^{2}$, N. U. Ndaeyo ${ }^{1}$, N. E. Nneke ${ }^{1}$ and G.U. Akpan ${ }^{3}$ \\ ${ }^{1}$ Department of Crop Science, Faculty of Agriculture, University of Uyo, Nigeria \\ ${ }^{2}$ Department of Agricultural Economics and Extension, Faculty of Agriculture, University of Uyo, Nigeria \\ 3Department of Soil and Land Resources Management, Faculty of Agriculture, University of Uyo, Nigeria
}

*Corresponding author.

\begin{abstract}
Discussions were held with cocoyam farmers in four Local Government Areas of Akwa Ibom State, Nigeria (Abak, Ibiono Ibom, Itu and Uyo) to obtain and assemble baseline information on cocoyam blight disease status and its effects on rural economy. Colocasia esculenta germplasm were collected from six cocoyam growing communities in Akwa Ibom State: (Ayadehe, Ikot Ada Idem, Ikot Ekang, Oku Abak, Midim and Afaha Oku) for growth, yield and blight disease tolerance evaluation for both screen house and field. This was with a view to identifying or developing resistant cultivars for the rural farmers who have depended on taro for food and income to meet their needs. Results in the screen house experiment indicated no apparent symptoms of cocoyam blight disease. Evaluation of growth characteristics and yield components demonstrated promising results. The reverse was the case for the field evaluation as severe symptoms of the disease were observed with some germplasm than others. The germplasm were therefore characterized into four accessions (Ce-Uy-1, Ce-Uy-2, Ce-Uy-3 and Ce-Uy-4) based on morphological characteristics, yield and resistance to the disease. Severe blight disease effects were observed for both the leaves and tubers of Ce-Uy-1, while Ce-Uy-2 had severe effect on leaves alone with no apparent effect on the tubers. The leaves and tubers of Ce-Uy-3 and Ce-Uy-4 showed some degree of tolerance and resistance respectively to the disease and therefore have potentials to be selected for multi-location trials and genetic and agronomic improvement/evaluation.
\end{abstract}

\section{Introduction}

Colocasia esculenta and Xanthosoma sagittifolium are two important species of cocoyam in Araceae family cultivated in southeastern and southwestern agroecologies of Nigeria (Pacumbab et al., 1992). Cocoyam constitutes an important staple for over 150 million people in developing countries (Chukwu et al., 2009). Nutritionally cocoyam is superior to cassava, yam and sweet potato based on its fibre content, digestibility,

\section{Article Info \\ Accepted: 31 March 2016 \\ Available Online: 06 April 2016}

\section{Keywords}

Cocoyam leaf blight disease Colocasia esculenta

Field evaluation

Resistant cultivars

Screen house crude protein, minerals and vitamins, particularly vitamins $B_{6}$ and $E$ (Lewu et al., 2010). Medically, cocoyam is particularly suitable for stomach regulation, prevention of diabetes, cancer, heart and kidney diseases. It is low in calorie, fat and sodium and thus makes it ideal food for preventing hardening of arteries which is caused by foods rich in cholesterol (Onwueme, 1987).

Cocoyam in its fresh state stores better than yam, cassava and potato and it is available in reasonable quantities 
throughout the year, ensuring regular supply of food and income for resource poor farmers (Sagoe et al., 2001). Cocoyam can also be processed into several food products and industrial materials similar to those of potato in the western world. It may be processed into such products as $f u f u$, soup thickener, flour for baking bread, biscuit, cake, chips, beverage powder, porridge and special foods for people with gastro-intestinal disorders and the convalescents (Onwuka et al., 2002). In Akwa Ibom and Cross River States, the popular local delicacies - Ekpang Nkukwo and Ekpang are prepared with taro (Udoh et al., 2010).

Of all the different kinds of cocoyam, taro (Colocasia esculenta) stands out due among others to high corm and cormel yields, early maturity, high palatability and ease of cooking. It had indeed served as food for many households, but since 1974, taro production in Nigeria had suddenly declined (Arene and Okpala, 1981) partly due to poor resource allocation for research, compared to cassava and yam (Okoye et al., 2000). In addition, the use of poor yielding cultivars and decreased cropping areas (Udoh et al., 2010), as well as cocoyam leaf and root rot blight complex (Mbanaso et al., 2008) have affected both growth and yield of the crop in the humid topics (Udoh et al., 2010). In recent years, several farmlands have been devastated by leaf blight resulting in the disappearance of the crop from the Nigeria markets (Adofo, 2004) and hence food table of the rural poor in particular. Besides, the livelihood of many rural farmers who depended on it for income either as occupation or for commerce purpose has been greatly affected. Wide spread of the disease has been reported in many West African countries (Adofo, 2004).

Taro leaf blight is caused by Phytophthora colocasiae (Raciborski). It is one of the most important economic disease of taro because it reduces corm yield of up to $50 \%$ (Singh et al., 2006) and leaf yield of up to $95 \%$ in susceptible genotypes (Nelson et al., 2011). Phytophthora colocasiae causes corms to rot both in the field and in the storage and this has led to heavy storage losses (Mbong et al., 2015). Development of new varieties through conventional genetic improvement method is not yielding meaningful result, for now (Udoh et al., 2010). Breeding efforts to improve taro is compounded in that flowering scarcely occurs and when induced, viable seeds are rarely set (Mbanaso and Nwachukwu, 2009). Worse still, the crop has very narrow genetic diversity suggesting that with the severity of the blight incidence if positive steps are not taken, the crop might face extinction with the rural-poor's situation worsening.
The objectives of this study were first to assess the occurrence and severity of the taro blight disease in Akwa Ibom State, Nigeria. Second, collect and characterize taro germplasm in Akwa Ibom State, evaluate and select the germplasm against the blight disease using both screen house, laboratory and field experiments. Third, determine the level of resistance to the disease and identify superior genotypes based on high yield and resistance to the disease.

\section{Materials and methods}

\section{Survey of incidence of the taro blight disease}

Cocoyam farmers in four Local Government Areas of Akwa Ibom State were visited and interviews and groups discussions held in July, 2013 to determine the extent of devastation of cocoyam farms by the cocoyam leaf blight and root rot disease and their effect on their livelihoods. The on-farm visitation, discussion and collection of cocoyam (taro) cultivars in the areas called for immediate rescue effort to prevent extinction of the cultivars. Information obtained though not part of this study showed that the people could no longer cultivate the crop due to the disease that usually strike at the critical stage of the crop development.

\section{Evaluation of cocoyam germplasm collections}

Screen house evaluation: The germplasm collected from farmers' plots in the four local government areas: Abak, Ibiono Ibom, Itu and Uyo were cleaned and placed in a cool dry place for screen house evaluation. Polythene bags were filled with sterilized top soil and the samples planted at $1 \mathrm{~m} \times 1 \mathrm{~m}$ using a complete randomized design with three replications on $16^{\text {th }}$ October, 2013. There were 72 plants and each genotype consisted of four plants, giving 24 plants per replicate. A prototype experiment was simultaneously carried out of the screen house as a check. The crops were watered in the morning every two days using clean water and administered at the base of the crop. Other data collected were height, leaf area, number of leaves per plant, number of cormels per plant, length of corms, girth of corms, fresh weight of corms and disease incidence. No fertilizer or agrochemical against pests was administered. The plants were harvested on $16^{\text {th }}$ April, 2014, about six months after planting. Three plants per genotype were tagged for data collection and their means subjected to analysis of variance and separated with the Least Significance Difference (LSD) at $5 \%$ probability level. 
Field evaluation: The taro germplasm from the screen house evaluation were cleaned and stored in a cool dry place for field planting at the University of Uyo Teaching and Research Farm, Use Offot, Uyo, Nigeria. The land was mechanically ploughed and harrowed and planting carried out on $23^{\text {rd }}$ April, 2014. The plants were spaced at $1 \mathrm{~m} \times 1 \mathrm{~m}$ apart giving 10,000 plants per hectare. The experiment occupied a land area of $35 \mathrm{~m} \mathrm{x}$ $23 \mathrm{~m}$ and was laid out in a randomized complete block design with four replications. The experiment was rain fed and no fertilizer and agro-chemical was applied for pest or disease control. The agronomic practices, characters studied and method of data analysis were similar to that of screen house evaluation. Four cocoyam genotypes with distinct morphological characters were distinguished and tagged per plot for growth, yield and blight disease data collection. The crops were harvested on $23^{\text {rd }}$ October, 2014.

Separate data were taken on each of the categories and labeled as Ce-Uy-1 for Congoma. Similarly, another type with the accession $\mathrm{Ce}-\mathrm{Uy}-2$, designated as Favourite was identified. Also, Ce-Uy-3 which was identified as the oldest genotype among them and designated as Uyo local, while Ce-Uy-4 was classified as Nkenge, an intermediate between Ce-Uy-2 and Ce-Uy-3. Analysis of variance was conducted for each character and the means separated with the Duncan Multiple Range Test (DMRT) at $5 \%$ probability level.

The accessions were evaluated for resistance to cocoyam blight disease following the procedure of Stather et al. (2003) and Williams (1989). Percentage of leaves or tubers per accession affected by the disease was determined using the formula:

Total number of plant/ tuber affected per accession Total number of plants/ tuber per accession

The scale and descriptor used to categorize the observed variations into classes of resistance and susceptibility were:

1. No apparent damage to plants (shoot) or tuber high resistance.

2. Very little damage - resistance (1-25\% of shoots or tubers affected by cocoyam blight disease).

3. Moderate damage - weak susceptibility (26-50\% damaged by the disease to either shoot or tuber).
4. Considerable damage - susceptibility (51-75\% damaged by the disease).

5. Severe damage - high susceptibility (76-100\% of plant part(s) affected by cocoyam blight disease.

The four accessions were also planted on $25^{\text {th }}$ December, 2014 and harvested on $25^{\text {th }}$ June, 2015 for further observation and comparison with the previous planting. However, the first three months of the plant life was sustained through irrigation, till the rain came fully in March, 2015. It was also intended to observe whether the crops could escape the disease before full maturity which usually occurs in July. The experiment which occupied a land area of $216.0 \mathrm{~m}^{2}$ was laid out in a randomized complete block design and replicated four times.

Characters studied were similar to those of the previous field planting. The crops were spaced $1 \mathrm{~m} \mathrm{X}$ $1 \mathrm{~m}$ apart, equivalent to 10,000 plants per hectare. Five plants were randomly selected and tagged per plot for data collection.

\section{Results and discussion}

\section{Screen house evaluation}

Significant differences $(p \leq 0.05)$ were observed among the taro accessions for all the characters studied (Table 1). The genotype from Oku Abak exhibited superior performance in four characters, namely height, number of leaves, leaf area and number of cormels per plant, followed by Ayadehe in one character (fresh weight of corms) and Ikot Ekang for length of corms. However, while Ikot Ada Idem recorded the lowest value for height, Midium was the lowest for number of leaves. Similarly, the lowest number of cormels per plant was given by Ayadehe.

No pathogenic symptom of cocoyam blight was observed among the cocoyam germplasm. A dusty white appearance on the upper surface of the leaves was diagnosed to be Basipetospora, a common fungus considered to be non-pathogenic to known crops. The appearance of the organism was however indicative of poor resistance by the cocoyam genotypes. But when some of the cocoyam genotypes were taken out of the screen house, the dusty white appearance gradually disappeared. 


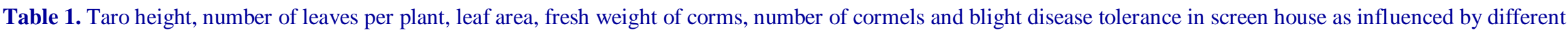
germplasm.

\begin{tabular}{|c|c|c|c|c|c|c|c|c|c|}
\hline \multirow{2}{*}{$\begin{array}{l}\text { Cocoyam accession/ } \\
\text { location }\end{array}$} & \multirow{2}{*}{$\begin{array}{l}\text { Taro height } \\
\text { (cm) }\end{array}$} & \multirow{2}{*}{$\begin{array}{l}\text { No. of leaves } \\
\text { per plant }\end{array}$} & \multirow{2}{*}{$\begin{array}{l}\text { Leaf area } \\
\left(\mathrm{cm}^{2}\right)\end{array}$} & \multirow{2}{*}{$\begin{array}{l}\text { Fresh wt. of corms } \\
\text { per plant (g) }\end{array}$} & \multirow{2}{*}{$\begin{array}{l}\text { No. of cormels } \\
\text { per plant }\end{array}$} & \multirow{2}{*}{$\begin{array}{l}\text { Length of } \\
\text { corms }(\mathrm{cm})\end{array}$} & \multirow{2}{*}{$\begin{array}{l}\text { Girth } \\
\text { corms }(\mathrm{cm})\end{array}$} & \multicolumn{2}{|c|}{ Disease score } \\
\hline & & & & & & & & Leaves & Tuber \\
\hline Itu-Ayadehe & $66.3^{c}$ & $4.3^{\mathrm{e}}$ & 293.9 & $244.2^{\mathrm{a}}$ & $3.4^{\mathrm{f}}$ & $4.0^{\mathrm{d}}$ & $4.2^{\mathrm{d}}$ & 1 & 1 \\
\hline Abak-Ikot Ekang & $68.3^{\mathrm{b}}$ & $5.4^{\mathrm{b}}$ & 319.5 & $226.4^{\mathrm{b}}$ & $4.7^{\mathrm{b}}$ & $6.1^{\mathrm{a}}$ & $4.6^{\mathrm{b}}$ & 1 & 1 \\
\hline Abak-Basin & $79.6^{\mathrm{a}}$ & $6.1^{\mathrm{a}}$ & 385.1 & $218.3^{c}$ & $6.4^{\mathrm{a}}$ & $5.2^{\mathrm{b}}$ & $5.6^{\mathrm{a}}$ & 1 & 1 \\
\hline Abak-Midim & $65.6^{\mathrm{c}}$ & $4.2^{\mathrm{f}}$ & 266.4 & $206.8^{d}$ & $3.8^{\mathrm{e}}$ & $4.6^{\mathrm{c}}$ & $4.4^{\mathrm{c}}$ & 1 & 1 \\
\hline Ibiono-Ikot Ada Idem & $46.3^{\mathrm{e}}$ & $4.5^{\mathrm{d}}$ & 305.4 & $199.4^{\mathrm{e}}$ & $4.0^{\mathrm{d}}$ & $3.2^{\mathrm{f}}$ & $3.8^{\mathrm{e}}$ & 1 & 1 \\
\hline Uyo-Afaha Oku & $60.7^{\mathrm{d}}$ & $5.0^{\mathrm{c}}$ & 286.4 & $184.4^{\mathrm{f}}$ & $4.2^{c}$ & $3.6^{\mathrm{e}}$ & $3.6^{\mathrm{f}}$ & 1 & 1 \\
\hline $\operatorname{LSD}(p<0.05)$ & 1.02 & 0.06 & 7.32 & 6.74 & 0.07 & 0.06 & 0.06 & NA & NA \\
\hline
\end{tabular}

Table 2. Growth and yield characteristics of Colocasia germplasm evaluated under field conditions at Use-Offot, Uyo, Akwa Ibom State, Nigeria.

\begin{tabular}{|c|c|c|c|c|c|c|c|c|c|c|c|}
\hline \multirow{2}{*}{$\begin{array}{l}\text { Cocoyam accession/ } \\
\text { location }\end{array}$} & \multirow{2}{*}{$\begin{array}{l}\text { Taro } \\
\text { height }(\mathbf{c m})\end{array}$} & \multirow{2}{*}{$\begin{array}{l}\text { No. of } \\
\text { leaves per } \\
\text { plant }\end{array}$} & \multirow{2}{*}{$\begin{array}{l}\text { Leaf area } \\
\left(\mathrm{cm}^{2}\right)\end{array}$} & \multirow{2}{*}{$\begin{array}{l}\text { Fresh wt. of } \\
\text { corms per } \\
\text { plant (g) }\end{array}$} & \multirow{2}{*}{$\begin{array}{l}\text { No. of } \\
\text { cormels } \\
\text { per plant }\end{array}$} & \multirow{2}{*}{$\begin{array}{l}\text { Length } \\
\text { of corms } \\
(\mathrm{cm})\end{array}$} & \multirow{2}{*}{$\begin{array}{l}\text { Girth of } \\
\text { corms } \\
(\mathrm{cm})\end{array}$} & \multirow{2}{*}{$\begin{array}{l}\text { Length of } \\
\text { cormels } \\
(\mathrm{cm})\end{array}$} & \multirow{2}{*}{$\begin{array}{l}\text { Girth of } \\
\text { cormels } \\
(\mathrm{cm})\end{array}$} & \multicolumn{2}{|c|}{ Disease score } \\
\hline & & & & & & & & & & Leaves & Tubers \\
\hline Itu-Ayadehe & $66.4^{\mathrm{d}}$ & $16.3^{\mathrm{d}}$ & $305.8 \mathrm{c}$ & $378.4^{\mathrm{e}}$ & $6.3^{\mathrm{f}}$ & $6.7^{\mathrm{d}}$ & $12.6^{\mathrm{e}}$ & $6.2^{\mathrm{e}}$ & $4.3^{\mathrm{d}}$ & 4 & 2 \\
\hline Abak-Ikot Ekang & $78.6^{\mathrm{a}}$ & $26.6^{\mathrm{a}}$ & $358.7 \mathrm{a}$ & $2240.7^{\mathrm{a}}$ & $16.8^{\mathrm{a}}$ & $17.6^{\mathrm{a}}$ & $28.4^{\mathrm{a}}$ & $15.2^{\mathrm{a}}$ & $8.8^{\mathrm{a}}$ & 5 & 2 \\
\hline Abak-Basin & $73.4^{\mathrm{b}}$ & $24.1^{\mathrm{b}}$ & $320.2 b$ & $2106.4^{\mathrm{b}}$ & $12.2^{\mathrm{b}}$ & $14.0^{\mathrm{b}}$ & $27.6^{\mathrm{b}}$ & $12.0^{\mathrm{b}}$ & $6.3^{\mathrm{b}}$ & 5 & 2 \\
\hline Abak-Midim & $69.2^{c}$ & $20.4^{\mathrm{c}}$ & $301.4^{\mathrm{c}}$ & $2041.5^{c}$ & $11.0^{\mathrm{c}}$ & $12.4^{\mathrm{c}}$ & $21.6^{\mathrm{c}}$ & $10.3^{c}$ & $4.3^{\mathrm{e}}$ & 5 & 2 \\
\hline Ibiono-Ikot Ada Idem & $63.4^{\mathrm{e}}$ & $14.2^{\mathrm{e}}$ & $279.6^{\mathrm{d}}$ & $464.6^{\mathrm{d}}$ & $6.8^{\mathrm{e}}$ & $6.8^{\mathrm{d}}$ & $14.6^{\mathrm{d}}$ & $7.2^{\mathrm{d}}$ & $5.6^{\mathrm{c}}$ & 3 & 1 \\
\hline Uyo-Afaha Oku & $64.2^{\mathrm{e}}$ & $15.4^{\mathrm{e}}$ & $272.4^{\mathrm{e}}$ & $365.8^{\mathrm{f}}$ & $8.9^{\mathrm{d}}$ & $5.6^{\mathrm{e}}$ & $12.8^{\mathrm{e}}$ & $7.6^{\mathrm{d}}$ & $4.4^{\mathrm{d}}$ & 3 & 1 \\
\hline
\end{tabular}

Mean with the same superscripts are not significantly different according to DMRT $(p<0.05)$. 
Table 3A. Agronomic characters yield and yield components and classification of Colocasia esculenta cultivars collected from Akwa Ibom State, Nigeria.

\begin{tabular}{|c|c|c|c|c|c|c|c|c|c|c|c|c|c|c|}
\hline \multirow{2}{*}{$\begin{array}{l}\text { Cocoyam } \\
\text { accession }\end{array}$} & \multicolumn{2}{|c|}{ Taro height $(\mathrm{cm})$} & \multicolumn{2}{|c|}{ No. of leaves } & \multicolumn{2}{|c|}{ Leaf area $\left(\mathrm{cm}^{2}\right)$} & \multicolumn{2}{|c|}{ Length of corm } & \multicolumn{2}{|c|}{ Girth of corms (cm) } & \multicolumn{2}{|c|}{ No. of cormels } & \multicolumn{2}{|c|}{ Length of cormels $(\mathrm{cm})$} \\
\hline & 2014 & 2015 & 2014 & 2015 & 2014 & 2015 & 2014 & 2015 & 2014 & 2015 & 2014 & 2015 & 2014 & 2015 \\
\hline Ce-uy-1 & $76.9 \mathrm{a}$ & 76.6 & $17.4 \mathrm{c}$ & 18.2 & $466.7 \mathrm{a}$ & 468.2 & $14.0 \mathrm{a}$ & 14.2 & $27.3 b$ & 27.6 & $8.6 \mathrm{c}$ & 8.6 & $15.2 \mathrm{a}$ & 15.6 \\
\hline Ce-uy-2 & $73.2 b$ & 73.4 & $28.6 \mathrm{a}$ & 29.2 & $412.1 b$ & 413.2 & $12.4 \mathrm{~b}$ & 12.2 & $36.0 \mathrm{a}$ & 36.4 & $18.4 \mathrm{a}$ & 18.6 & $12.2 b$ & 12.4 \\
\hline Ce-uy-3 & $64.4 c$ & 65.0 & $14.8 \mathrm{~d}$ & 14.5 & $259.8 d$ & 259.9 & $4.2 \mathrm{~d}$ & 4.6 & $9.6 \mathrm{~d}$ & 9.2 & $9.3 b$ & 9.4 & $70.0 \mathrm{~d}$ & 7.2 \\
\hline Ce-uy-4 & $57.3 \mathrm{~d}$ & 58.1 & $20.1 b$ & 20.6 & $302.8 \mathrm{~d}$ & 304.2 & $5.8 \mathrm{c}$ & 5.9 & $16.5 \mathrm{c}$ & 16.8 & $6.2 \mathrm{~d}$ & 6.1 & $8.5 \mathrm{c}$ & 8.6 \\
\hline $\operatorname{LSD}(p<0.05)$ & 3.02 & 3.01 & 1.06 & 1.07 & 6.86 & 6.87 & 0.08 & 0.08 & 1.07 & 1.08 & 0.16 & 0.16 & 0.24 & 0.24 \\
\hline
\end{tabular}

Table 3B. Agronomic characters yield and yield components and classification of Colocasia esculenta cultivars collected from Akwa Ibom State, Nigeria.

\begin{tabular}{|c|c|c|c|c|c|c|c|c|c|c|}
\hline \multirow{3}{*}{ Cocoyam accession } & \multicolumn{2}{|c|}{ Girth of corms (cm) } & \multicolumn{2}{|c|}{ Fresh wt of corm and cormels (g) } & \multicolumn{2}{|c|}{ Salable cormels } & \multicolumn{4}{|c|}{ Disease score } \\
\hline & \multirow{2}{*}{2014} & \multirow{2}{*}{2015} & \multirow{2}{*}{2014} & \multirow{2}{*}{2015} & \multirow{2}{*}{2014} & \multirow{2}{*}{2015} & \multicolumn{2}{|c|}{ Leaves } & \multicolumn{2}{|c|}{ Tubers } \\
\hline & & & & & & & 2014 & 2015 & 2014 & 2015 \\
\hline Ce-uy-1 & $8.5 \mathrm{c}$ & 8.5 & $589.2 b$ & 589.6 & $0 \mathrm{~d}$ & 0 & 5 & 5 & 3 & 3 \\
\hline Ce-uy-2 & $15.3 \mathrm{a}$ & 15.6 & $2112.7 \mathrm{a}$ & 2114.2 & $5.4 \mathrm{a}$ & 5.3 & 5 & 5 & 1 & 1 \\
\hline Ce-uy-3 & $10.2 b$ & 10.4 & $357.6 \mathrm{~d}$ & 356.8 & $1.8 b$ & 1.8 & 3 & 3 & 1 & 1 \\
\hline Ce-uy-4 & $6.1 \mathrm{~d}$ & 6.0 & $426.5 c$ & 425.9 & $0.6 \mathrm{c}$ & 0.7 & 4 & 4 & 1 & 1 \\
\hline LSD $(p<0.05)$ & 0.72 & 0.72 & 9.76 & 9.77 & 0.006 & 0.006 & NA & NA & NA & NA \\
\hline
\end{tabular}




\section{Field evaluation}

Significant differences $(p \leq 0.05)$ were observed among the cocoyam germplasm for all the characters studied, with Ikot Ekang and Oku Abak each leading in three characters (Table 2). The lowest performance was observed for Afaha Oku and Ikot Ada Idem, although both accessions showed superiority in resistance to cocoyam leaf blight disease. Three genotypes (Ayadehe, Ikot Ada Idem and Afaha Oku) were earlier introduced cultivars which have been cultivated for decades, while those obtained from Abak Local Government Area were probably cultivars with higher yields released later (Congoma) to replace the adapted cultivars hence, their poor resistance status. Kulkarni and Chopra (2005) noted that resistance may be found in locally adapted cultivars. Although the three germplasm are not high yielding as their counterparts from Abak, suggested that they could be selected for tolerance (Politowski and Browning, 1978).

The cocoyam, germplasm were characterized based on differences in morphological traits in addition to disease resistance. Four distinct types were identified based on size of corm, alignment of cormels and size of cormels. They were Ce-Uy-1 (Congoma) which possesses long corms with long cormels. The cormels grew away from the corm, constituting a circle around the corm. The cormels were slender or tapered towards points of attachment to the corm while the corm constitute the edible portion; about 8-10 cormels were borne by one corm; Ce-Uy-2, designated "Favourite" which consisted of very large corms with 14-30 cormels some of which were very large in size. The cormels congregated or clustered about the corm. This cultivar possessed high prolificacy of cormels, giving the best yield.

The accession, Ce-Uy-3 locally called Panya which has been cultivated for several decades consists of small corms and small cormels. They are more adaptable to the high humid environment than the other accessions. Similarly, the Ce-Uy-4 had moderate size corm and cormels. The arrangement of its cormels fell between Congoma and Favorite. The cormels distanced from the corm about $5-10 \mathrm{~cm}$ in the field, though not so wide as in Congoma. The result indicated Ce-Uy- 1 and Ce-Uy-2 as the most susceptible accessions to blight disease, although for Ce-Uy-2 the tuber was not affected by the disease. The other accessions, $\mathrm{Ce}-\mathrm{Uy}-3$ and $\mathrm{Ce}-\mathrm{Uy}-4 \mathrm{had}$ moderate resistance to the disease and could be considered as possible candidates for further breeding purpose, although their yields were lower (Table 3). Visual assessment revealed that the disease symptoms increased with increase in rainfall and could be so correlated, such that by July the susceptible ones were completely devastated in the field. The crops which were planted on 25 December, 2014 under irrigation for the first three months, followed by rainfall showed less severe attack since they matured in June, 2015 compared with the previous crops which were planted in April, 2014 under rain fed condition.

\section{Conclusion}

Farmers no longer cultivate Colocasia esculenta in Akwa Ibom State, Nigeria due to the devastating cocoyam root rot and leaf blight disease. The rural economy depended so much on the crop due to its early maturity, promising yields, high nutritional value, quick return to investment and low content of calcium oxalate and acridity and longer shelf life compared to other cocoyam species. Some cultivars in this study have been identified with tolerance to the diseases, although their yields are not very high compared to highly susceptible ones with high yield. There is hope that with continuous evaluation and appropriate breeding and agronomic strategies development of resistant cultivars in the nearest future will be possible. Mixed cropping and early planting could be some of the keys to unlock solution to the disease. The research is on-going and positive results are on sight.

\section{Conflict of interest statement}

Authors declare that they have no conflict of interest.

\section{Acknowledgement}

The principal author acknowledges the technical and financial supports of the Team leader, Professor G. S. Umoh and Prof. N. U. Ndaeyo, both of the Faculty of Agriculture, University of Uyo, Nigeria.

\section{References}

Adofo, K., 2004. Morphological characterization and evaluation of local Cocoyam (Xanthosoma sagittifolium (L.) Schott, germplasm for disease resistance, A Thesis Submitted to the College of Agriculture and Natural Resources, Kweme Nkruma University of Science and Technology, Ghana.

Arene, O. B., Okpala, E. U., 1981. A disease of Cocoyam caused by Corticium rolfsii. In: Tropical Root Crops: Research Strategies for the 1980s (Eds.: Terry, E. R., Oduro, K. A., Converse, F.). International Development Research Centre, Ottawa, Canada. pp.237-240. 
Chukwu, G. O., Nwosu, K. I., Madu, T. U., Chinaka, C., Okoye, B. C., 2009. Development of gocing storage method for cocoyam. Proceedings of the $43^{\text {rd }}$ Annual Conference of the Agricultural Society of Nigeria. pp. 960-962.

Kulkarni, R. N., Chopra, V. L., 2005. Breeding for disease resistance. In: Plant Breeding Theory and Practice (Ed.: Chopra, V. L.). Mohhan Primlani, New Delhi, India. pp.133-169.

Lewu, M. N., Adebola, P. O., Afolayan, A. J., 2010. Comparative assessment of nutritional value of commercially available cocoyam and potato tubers in South Africa. J. Food Qual. 33 (4), 461-476.

Mbanaso, E. N. A., Nwachkwu, E. C., 2009. Radiation sensitivity in different cultivars of cocoyam. Proceeding of the $43^{\text {rd }}$ Annual Conference of the Agricultural Society of Nigeria held at the National Universities Commission and RMRDC., Abuja on $20^{\text {th }}-23^{\text {rd }}$ October, 2009. pp. 224-227.

Mbanaso, E. O., Nwakor, F. N., Mbanaso, E. N. A., Asumugha, G. N., Abachi, U., 2008. Guide to Cocoyam Minisett Production, Extension Guide No. 22, Extension Services Programme, N. R. C. R, Umudike, Nigeria. pp.110.

Mbong, G. A., Fokunang, C. N., Manju, E. B., Njukeng, A. P., Tembe-Fokunang, E. A., Itanna Rachid, 2015. Mycelia growth and sporulation of Phytopthora colocasiae isolates under selected conditions. Amer. J. Exp. Agric. 8(4), 193201.

Nelson, S., Brooks, F., Teves, G., 2011. Taro Leaf Blight in Hawaaii, Plant Diseases Bulletin No. PD-71, Universtiy of Hawaaii, Manoa HI, USA, New Caledonia. 118p.

Okoye, B. C., Asumgha, G. N., Okezie, C.A.,Tanko, L., Onyenweaku, C.E., 2008. Econometric assessment of the trend in cocoyam production in Nigeria, 1960-2006. Agric. J. 3(2), 99-101.

Onwueme, I. C., 1987. Strategies for increasing cocoyam (Colocasia and Xanthosoma spp.) in Nigeria food market.
Proceedings of the First Worship on Cocoyam. National Root Crops Research Institute, Umudike, Nigeria. 58p.

Onwuka, G. I., Udensi, E. A., Azubike, M., 2002. Potentials of cocoyam in bakery and production of chips. J. Sustain. Agric. Environ. 4(1), 64-70.

Pacumbaba, R.P., Wutch, J.C., Meboka, M.M.B., 1992. Protocol to screen cocoyam accessions for resistance or tolerance to cocoyam root not disease in Cameroon. Amer. Phytopath. Soc. J. Plant Dis. 76(8), 768-770.

Politowski, K., Browning, J. A., 1978. Tolerance and resistance to plant disease: An Epidemiological study. Physiopathol. 68, 1178-1185.

Sagoe, R., Marfo, K. A., Dankyi, A. A., 2001. The potential of cocoyam production in Ghana. Root Crops in the $21^{\text {st }}$ Century. Proceedings of the $7^{\text {th }}$ Triennial Symposium of the International Society Tropical Root Crops, African Branch. pp.250-260.

Singh, D., Guaf, J., Okpul, T., Wides, G., Hunter, D., 2006. Taro (Colocasia esculenta) variety release recommendations for Papua New Guinea based on multi location trials. J. Crop Hortic. Sci. 34, 163-171.

Stathers, T. E., Rees, F., Kabi, S., Mbilinyi, L., Smith, N. M., Koizya, H., Jeremiah, S., Nyango, A., Jeffries, D., 2003. Sweet potato infestation by Cylas species in East Africa: 1. Cultivar differences in field manifestation and the role of plant factors. Int. J. Pest Manag. 49, 131-140.

Udoh, V. S., Ndaeyo, N. U., Bassey, E. E., 2010. Profitability of cocoyam production as affected by tillage methods and fertilizer application in Southeastern Nigeria. Proc. $5^{\text {th }}$ Int. Conf. Scient. Indust. Stud. 5(2), 55-58.

Williams, P. H., 1989. Streamlining for resistance to disease. In: The Use of Plant Genetic Resources (Brown, A. H. D., Franked, O. H., Marshall, D. R., Williams, J. T.). Cambridge University Press, Cambridge. pp.350-352.

\section{How to cite this article:}

Bassey, E. E., Umoh, G. S., Ndaeyo, N. U., Nneke, N. E., Akpan, G.U., 2016. Investigations into taro [Colocasia esculenta (L.) Schott] leaf blight outbreak and identification of resistant cultivars in Akwa Ibom State, Nigeria. Int. J. Curr. Res. Biosci. Plant Biol. 3(5), 137-143. doi: http://dx.doi.org/10.20546/ijcrbp.2016.305.021 